\title{
MODERATING EFFECT OF INSTITUTIONAL QUALITY ON RELATIONSHIP BETWEEN FOREIGN AID AND ECONOMIC GROWTH IN AFRICA
}

\author{
Oliver E. Ogbonna ${ }^{a}$, Jonathan E. Ogbuabora (iD, Afamefuna A. Eze ${ }^{a}$, \\ Walter O. Ugwuoke ${ }^{b}$
}

\begin{abstract}
Africa has received considerable amounts of external aid over the last two decades without significant improvements in socio-economic conditions on the continent. This study, therefore, examines the effects of foreign aid on growth in Africa, and how institutional quality can moderate these effects. The study used the system generalized method of moments estimation technique and a panel of forty-two African countries over the period 2010-2018. Interestingly, the study established that even though foreign aid impacts negatively on growth in Africa, improving the quality of institutions on the continent can reverse this negative effect. In fact, the study computed a threshold value of institutional quality beyond which foreign aid would be a blessing to Africa. This implies that for foreign aid to contribute meaningfully to growth in Africa, the quality of institutions should improve beyond this threshold. Unfortunately, the average level of institutional quality in Africa is presently below this threshold. The study concluded that policymakers in Africa should take urgent steps to strengthen the quality of institutions on the continent as a means of exploiting the continent's huge foreign aid to drive growth and reduce the excruciating effects of poverty plaguing more than half of its population.
\end{abstract}

Keywords: Foreign aid, institutional quality, economic growth, system GMM, Africa JEL Classifications: F35, N20, F43, C23, N17

\section{Introduction}

Africa, a continent with a population above one billion (about $15 \%$ of the world's population and the second-largest region behind Asia) is a continent plagued with high levels of poverty, weak development of human capital, and infrastructural decay. Africa also

\footnotetext{
a University of Nigeria, Nsukka, Nigeria

b Department of Economics, Federal University Lafia, Nasarawa State, Nigeria

E-mail: oliver.ogbonna@unn.edu.ng; jonathan.ogbuabor@unn.edu.ng;

afamefuna.eze@unn.edu.ng; ugwuokemartins@yahoo.com
} 
has a low share of world trade as it accounts for $2.97 \%$ and $2.34 \%$ of world imports and exports, respectively. Twenty-seven out of the twenty-eight poorest countries in the world are in Sub-Saharan Africa with a poverty rate above 30\% according to the World Bank's 2018 Poverty and Shared Prosperity Report. Also, after more than two decades, the proportion of the population living on less than US $\$ 1.9$ per day fell from $54 \%$ in 1990 to $42 \%$ in 2015 , which is just a $12 \%$ decline (World Bank, 2020). Indeed, the poverty headcount ratio stood at $66 \%$ and $84 \%$ for US\$3.2 per day and US\$ 5.5 per day in 2015 , respectively, which are quite worrisome. In fact, the economy of Africa is faced with multi-faceted challenges, which manifest socially, economically and politically. Some of these challenges have been attributed to conflicts, weak infrastructure, structural imbalances and weak institutions. Another factor linked to the higher levels of poverty in Africa is the vulnerability to fluctuations on the world market, due to its precarious dependence on mineral resources and agricultural exports, coupled with a small and inefficient industrial base, huge external debt, internal power tussle, and institutional failure (Schmieg, 2015). These have deluged Africa with a heap of problems, which seem difficult to eradicate.

Obviously, one of the questions that need urgent attention is why African economies have consistently performed poorly over a long period of time, even though policy approaches as veritable tools of reforming economies to improve performance are well documented in the literature (Kalirajan and Otsuka, 2014). Put differently, why are richer and more advanced countries in Europe, America and Asia recording better economic performance than African economies, contrary to the postulations of the convergent hypothesis distilled from the Solow model? The model predicted that poor countries would grow relatively faster than rich ones as the rate of return on capital is higher in poor countries, and thus, in the long run, both poor and rich countries would converge at their balance growth path (Edwards, 2015). The fascinating implication of this hypothesis is that poverty should disappear by itself in the long run, so that one would expect the poor countries in Africa to catch up with the rich and more advanced countries in Europe, America and Asia since a country's relative position on the world development ladder is not immutable (Romer, 2012). Unfortunately, Africa has persistently remained abysmally poor over the years.

The experience of Western development that started after the first industrial revolution due to Western capital formation and accumulation of technological progress, led to a popular belief among economists and policymakers that these two factors are capable of creating the impetus for economic development in Africa, which had long suffered from foreign exchange and savings gaps that led to low rates of capital formation. This notion that capital and technological know-how have positive relationships with development led to the emergence of official development assistance as a means of instilling the missing ingredients and/or a prerequisite for meeting not only international development targets 
but also eliminating poverty. Consequently, the Organization for Economic Cooperation and Development (OECD) defined official development assistance as grants targeted at the recipient country's economic development and welfare, and concessional loans (with zero or low interest rates) that contain grant components of at least 25 percent targeted mainly at the recipient country's economic development and welfare. This has become an important discourse in policy relations of the African region. In this context, Acemoglu and Robinson (2010a) explained that foreign aid to Africa was necessitated by the economic downturn resulting from limitations imposed by the economy-specific institutional framework and its quality, low capital per worker and technological progress.

Despite the unprecedented huge foreign aid that has been allocated to Africa over the years, the region has consistently wallowed in abject poverty. Table 1 illustrates the economic outlook amidst the foreign aid inflows.

Table 1: Foreign aid inflows and number of extremely poor, by region, 2005-2015

\begin{tabular}{|c|c|c|c|c|c|c|}
\hline \multirow[b]{2}{*}{ Region } & \multicolumn{3}{|c|}{$\begin{array}{l}\text { Foreign aid inflows } \\
\text { (billions of US dollar) }\end{array}$} & \multicolumn{3}{|c|}{$\begin{array}{l}\text { Number of extremely poor } \\
\text { (millions) }\end{array}$} \\
\hline & 2005 & 2015 & $\begin{array}{c}\text { point } \\
\text { change, } \\
2005-2015\end{array}$ & 2005 & 2015 & $\begin{array}{c}\text { point } \\
\text { change, } \\
2005-2015\end{array}$ \\
\hline East Asia \& Pacific & 9.27 & 8.53 & -0.74 & 356.99 & 47.01 & -309.98 \\
\hline Europe and Central Asia & 4.95 & 8.55 & 3.60 & 22.87 & 7.82 & -15.05 \\
\hline Latin America \& the Caribbean & 6.46 & 10.30 & 3.84 & 54.90 & 25.32 & -29.58 \\
\hline Middle East \& North Africa & 28.26 & 19.31 & -8.95 & 9.38 & 14.07 & 4.69 \\
\hline South Asia & 9.02 & 15.70 & 6.68 & 509.96 & 215.23 & -294.73 \\
\hline Sub-Saharan Africa (SSA) & 32.83 & 44.77 & 11.94 & 386.45 & 419.56 & 33.11 \\
\hline
\end{tabular}

Source: Authors' compilation, with data from the World Bank's World Development Indicators (WDI) and PovcalNet (http://iresearch.worldbank.org/PovcalNet/)

Notwithstanding the substantial increase in foreign aid inflows as shown in Table 1, Sub-Saharan Africa (SSA) is the only region globally where the number of extremely poor people increased by more than 33 million, from 386.45 million in 2005 to 419.56 million in 2015. Surprisingly, SSA had more extremely poor individuals than the rest of the world put together. Whereas the extreme poverty rate for other regions was found to be less than $13 \%$, that of SSA was above $41 \%$ in 2015 . Moreover, countries in SSA made up just $28 \%$ of the extremely poor population globally in 2005 , whereas in 2015 this share rose to $56 \%$. 
The literature has largely attributed the state of underdevelopment in Africa to the failure of economic and political institutions. Dias and Tebaldi (2012) revealed that the structure of an institution in a state is shaped by the historical antecedents of the economy with the attendant effect on long-term economic performance. Africa's paradigm shift from colonialism did not generate a transition from the extractive to an inclusive institutional sphere. Instead, the post-colonial African countries basically denote an imitation of the extractive institutions of colonial masters in African outfits (Acemoğlu and Robinson, 2010a). Therefore, the present post-colonial African states still retain the exploitative instrument of colonial rule and as such lack the will to spur the welfare of their citizens. This type of institution provides a hostile environment that breeds inequality, injustice and uncertainty, which are inimical to innovation and growth. As a result, it is likely that foreign aid inflows may not have the capacity to engender development in this type of setting. Acemoğlu and Robinson (2012) contended that economic policy, value system, culture, or geography do not guarantee success or failure of any nation; rather, success or failure of nations depends on their institutions. They argued that political institutions define a nation's economic institutions, which ultimately determine the success or failure of the nation. North (1990) revealed direct and indirect effects of the institutional framework on economic growth. The study argued that governments with healthy institutions allocate state resources efficiently and create conducive environment and the needed confidence for economic agents to thrive by lowering the risks and costs of transactions. However, a number of factors such as bureaucratic obstacles, bribery and rent-seeking behaviour could lead to inefficiency in utilization of state resources, which ultimately result in distrust and disincentive to investment and thus, economic stagnancy.

Experience gained from the 2008-2009 Global Financial Crisis (GFC) is quite relevant in today's Africa given that most African economies have been impelled into similar economic conditions by the ongoing Covid-19 pandemic. The economic impact of the GFC and the financial easing efforts that came with it were quite huge. Most African economies witnessed reduced fiscal revenues and increased external aid. This external aid proved necessary to sustain basic government operations. The ongoing Covid-19 pandemic has induced an economic crisis in African economies that can be likened to the GFC. The post-GFC period witnessed an unprecedented rise in inflows of foreign aid to SSA, though the effect on the economy is not yet clear. However, as shown in Table 1, the welfare rate in the post-crisis period worsened as the poverty rate deteriorated from $28 \%$ in 2005 to $56 \%$ in 2015 notwithstanding the huge inflow of foreign aid. The World Bank and the International Monetary Fund have predicted that this novel Covid-19 could lead to another global recession worse than the GFC, while the poorest economies would be more vulnerable given their fragilities and financial constraints. 
This study therefore seeks to evaluate how institutional quality dynamics can shape the efficacy of foreign aid in engendering economic performance in Africa. This is because, despite the fact that several insightful studies have explored the effect of foreign aid on growth, what remains as an obvious gap in the existing literature is the fact that how institutional quality moderates the effects of foreign aid on growth in Africa is yet to be explored empirically. Studies (for example, Brambor et al., 2006; Ehigiamusoe and Lean, 2019) have shown that a given variable could influence or alter the relationship between two other variables, which in turn suggests a conditional hypothesis. Therefore, the problem necessitating this study lies in the fact that at this time, it is unknown whether foreign aid effects on economic performance in Africa differ with the level of institutional quality. Essentially, foreign aid may have not only a direct impact but also an indirect impact on economic performance through institutional quality. In other words, revealing how institutional quality interacts with foreign aid will greatly enrich the robustness of the existing evidence about the relationship between foreign aid and economic performance in Africa. This thinking is applied empirically in this study by the inclusion of multiplicative interaction terms in the study model. Following the estimation of this model, the marginal effect was also computed, and this confirmed that the effect of foreign aid on economic performance differs with the level of institutional quality. As a result, the study computed institutional quality thresholds required for foreign aid before economic performance can be unhindered. This is important because foreign aid reform alone, as suggested by previous studies, may not drive economic performance unless other fundamental factors, such as institutional quality, which may cause differences in the proximate measure across countries, are substantially accounted for in explaining the efficacy of foreign aid.

\section{Literature Review}

The theoretical underpinning of the relationship between foreign aid and growth can be traced to the standard neoclassical growth model of Solow (1956) and Swan (1956). The model states that the steady-state or long-run level of output per capita of an economy depends on physical capital and population. The higher the capital stock, the richer the economy; and the higher the population growth rate, the poorer the economy, and vice versa. Thus, poor economies face a capital gap and, subject to additional capital stock, may experience faster growth. This assertion is consistent with "big push theory", which explains that bridging the capital gap with foreign aid will lift an underdeveloped economy out of poverty and it will start to grow by itself in a sustainable manner (Sachs, 2005). Therefore, foreign aid can augment the existing capital stock of the recipient economy, and this in turn can lead to more economic growth. 
Following this theoretical postulation, an aspect of the literature believes that underdevelopment is a result of capital inadequacy (Sachs, 2005). This popular mindset that aid has positive correlation with development motivated the rich countries to extend aid to developing nations in order to bridge resource gaps. However, with diminishing returns to capital stock, the foreign aid effect on growth could be adjudged to be temporal except if aid leads to a rise in total factor productivity growth or human capital accumulation that are robust to growth in the long term. As a result, the inconclusive debate about the effectiveness of external aid in stimulating economic performance has remained a controversial issue. Consequently, several studies have investigated the effect of foreign aid dependency on the economy, but the findings are widely divided about the nature of this relationship. The optimists argue that the relationship between foreign aid and welfare is positive (Hansen and Tarp, 2000; Burnside and Dollar, 2000; Devarajan et al., 2002; Christensen et al., 2011; Clemens et al., 2012; Juselius et al., 2014; Lof et al., 2015), but other analysts argue that foreign aid cannot induce development (Bräutigam and Knack, 2004; Rajan and Subramanian, 2005; Djankov et al., 2008; Moyo, 2010; Kalu, 2018).

The foreign aid optimist school of thought argues that aids are agents of growth and development in the recipient countries. They opined that aid would greatly help to foster economic growth and development especially in productive sectors such as health and education, which are greatly responsible for the accumulation of human capital in most developing countries (Christensen et al., 2011; Devarajan et al., 2002). Morrissey (2001) outlined several channels through which aid impacts on growth, which include: (i) foreign aid enhances investment in both human and physical capital; (ii) foreign aid improves the capacity to import capital goods; and (iii) foreign aid promotes technology diffusion, which in turn drives productivity. Perhaps aid is obviously good and has contributed to the quality of human welfare, especially targeted humanitarian aid with defined objectives such as public health and education. As noted by Christensen et al. (2011), targeted primary education aid expands school enrolment opportunities, suggesting that humanitarian aid will help in boosting the health status and education level of the recipient countries, thereby improving the labour force productivity.

Based on the foregoing, there is a long-standing controversy on whether foreign aid puts any stimulus upon the growth of Africa's economy. Ekanayake and Chatrna (2010) employed an ordinary least square model to analyse how foreign aid fosters economic growth across regional economies covering the period from 1980 to 2007. The study found that foreign aid impacts positively on growth in the African region, whereas foreign aid had negative or negligible influence on growth in both Asia and Latin America. In another study, Maruta et al. (2020) examined various effects of foreign aid on growth in three regions comprising 74 developing economies in South America, Asia and Africa covering 
the period 1980-2016. The results show that foreign aid to health and education was sizable in enhancing economic growth across the regions, while foreign aid to agriculture had growth-enhancing impact in South America. However, in Asia and Africa, foreign aid to agriculture had an insignificant relationship with growth.

Furthermore, aid reduces the costs of doing business, thereby raising the productivity and gain of the private sector by allowing additional government expenditure through direct development assistance on infrastructure, security and other socio-economic services such as power supply, good road networks, superior security gadgets, among others, or indirect development assistance such as budget support. Clemens et al. (2012) lend support to this by their assertion that a significant rise in aid inflow causes on average a little but non-zero rise in the rate of investment and profitability. However, the findings further suggest that the positive effect of aid on economic growth across states is relatively small when compared to other factors affecting growth. A similar study by Juselius et al. (2014) revealed that foreign aid to 27 out of the 36 SSA countries exhibit positive long-run influence on investment and growth. They argued that the effect of aid depends on country-specific characteristics. This suggests that foreign aid in an open economy with a modest inflation rate and trifling budget deficits engenders growth (Lof et al., 2015). Burnside and Dollar (2000) also established positive and statistically significant long-run effects of aid on income, while Hansen and Tarp (2000) also found a positive relationship between foreign aid and growth.

The foregoing paragraphs indicate that the empirical evidence is not uniformly one-sided regarding the effect of foreign aid on growth and development. Even though some existing studies argue that foreign aid is a blessing, the stylized facts in Africa point to the contrary. Empirical studies that lend support to the bulk of prevailing criticisms against the role of foreign aid in Africa abound. Kalu (2018) found that foreign aid to Africa is not engendering real development and cannot move the continent out of poverty line. The study argued that while foreign aid is useful, to some extent, in safeguarding lives, especially during periods of crisis such as war and famine, it cannot engineer real development paths. In line with this view, the literature has documented the potential adverse effects of unearned income such as foreign aid. For instance, the so-called "natural resource curse" has always been used to illustrate the negative effect of rent accruing from natural resources that represent unearned income in a developing economy. Foreign aid shares this similar feature of rent-seeking behaviour, signalling an "aid curse" as well, which may undermine development in the overall economy (Kang et al., 2012). This reflects the issue of "Dutch disease", as the huge foreign aid inflow of dollars and other hard currencies will perhaps drive up the values of local currencies, creating added challenges for exportoriented industries and agriculture (Moyo, 2010). It equally suggests that foreign aid 
has the potential of weakening export incentives; thus, it is detrimental to growth and development. This argument is supported in the work of Rajan and Subramanian (2005), who found that a country's competitiveness is hampered by foreign aid and consequently, both the share of commodity- and labour-intensive industries, such as agriculture, decrease as a result of exchange rate overvaluation that stems from foreign aid.

From another perspective, an economy that depends on large volumes of foreign aid (unearned income) reduces the pressure on citizens to seek accountability on state resources as opposed to revenue resources generated from taxpayers. Basically, if the need to tax citizens decreases as a result of the high inflow of foreign aid, the incentive for individual involvement in the political process decreases. Consequently, a state with a high volume of foreign aid implicitly has less incentive to optimize the use of state resources since there is no pressure to account for such resources (Bräutigam and Knack, 2004). As a result, policies such as liberal trade that enhance agriculture, manufacturing and other sectors will receive less support. Consequently, such sectors will be weakened and rendered less competitive. These arguments follow the stance of Djankov et al. (2008) that foreign aid is a syndrome that weakens the checks and balances in an economy, and thus does not support democracy.

\section{Methodology}

The roles that capital, labour and technological progress play are quite fundamental in the new growth theory. The basic AK model as presented by Pagano (1993) specified that output is a function of capital stock and factor productivity, that is,

$$
Y=A K_{t}
$$

where $Y$ denotes aggregate output, $A$ denotes total factor productivity, and $K$ represents capital stock. However, the literature has also identified other factors that could impact on aggregate output growth (measured in this study as real GDP per capita growth). Examples of such factors include trade openness (TOP), labour $(L)$ and institutional quality $(I Q)$. The growth framework in Equation (1) is therefore extended by including these relevant factors as follows:

$$
Y_{i t}=\alpha_{i}+\beta_{i 1} A I D_{i t}+\beta_{i 2} C O C_{i t}+\beta_{i 3} A I D \times C O C_{i t}+\beta_{i 4} T O P_{i t}+\beta_{i 5} K_{i t}+\beta_{i 6} L_{i t}+\varepsilon_{i t}
$$

where AID denotes foreign aid measured as net official development assistance and official aid received expressed in percent of GDP; COC denotes control of corruption, a proxy for institutional quality; $A I D \times C O C$ denotes the interaction term between foreign aid and institutional quality, which is used to investigate how institutional quality moderates the effect of foreign aid on economic growth (which, in turn, is the measure of economic 
performance in this study); and is the error term. Following Arellano and Bond (1991) and Blundell and Bond (1998), the model for this study, which was estimated using the generalized method of moments (GMM) technique, is specified as follows:

$$
y_{i t}=\alpha_{i}+\phi_{i 1} y_{i t-1}+\beta_{i 1} a_{i d}+\beta_{i 2} \operatorname{coc}_{i t}+\beta_{i 3}\left(\operatorname{aid}_{i t} \times \operatorname{coc}_{i t}\right)+\beta_{i 4} t_{o p}+\beta_{i 5} k_{i t}+\beta_{i 6} l_{i t}+\varepsilon_{i t}
$$

where the lowercase variables indicate the natural log of the respective uppercase variables; $y_{i, t}$ denotes the dependent variable, which is economic growth measured as real gross domestic product per capita growth of the various countries; $y_{i, t-1}$ denotes the lagged value of $y_{i, t}$; while $\alpha_{i}, \beta_{i 1}, \beta_{i 2,}, \beta_{i 3} \beta_{i 4}, \beta_{i 5}$ and $\beta_{i 6}$ are parameters to be estimated; i stands for the cross-sectional index $(i=1,2,3, \ldots, 42) ; t$ stands for the time period (that is $t=2010,2011, \ldots, 2018$ ).

This study is particularly interested in the marginal effect of a change in foreign aid on economic growth, and how this change is influenced by the level of institutional quality. Hence, the marginal effect is computed via the partial derivative of Equation (3) with respect to foreign aid. This partial derivative of the growth variable with respect to foreign aid (see Appendix 1 for the details of the computation of this partial derivative) is given by:

$$
\frac{\partial y_{i t}}{\partial a i d_{i t}}=\left[1 /\left(1-\phi_{i t}\right)\right]\left(\beta_{1}+\beta_{3} \operatorname{coc}_{i t}\right)
$$

Thus, the focal point of this study is on the coefficients in the partial derivative equation. If $\beta_{1}>0$ and $\beta_{3}<0$, it implies that foreign aid is a blessing while the institutional quality is adversely influencing that blessing. The adverse influence of institutions diminishes as institutional quality improves, indicating that whether foreign aid is a blessing or curse depends on the level of institutional quality in an economy, which suggests the presence of a threshold effect. If $\beta_{1}<0$ and $\beta_{3}>0$, it signals that foreign aid is a curse while institutional quality moderates that curse in Africa. However, if the two parameters carry positive signs, it signals that an increase in foreign aid would be a blessing to African economies, and improved institutional quality would intensify that blessing. However, if the two parameters carry negative signs, it signals that an increase in foreign aid would lead to a decrease in aggregate output, while poor institutional quality would heighten the decrease. To provide robustness checks on the results of this study, the model was re-estimated using government effectiveness as an alternative measure of institutional quality.

\subsection{Data and estimation technique}

The underlying model in Equation (3) was estimated using panel data for a sample of 42 countries, namely Algeria, Angola, Benin, Botswana, Burkina Faso, Burundi, Cabo Verde, Cameroon, Chad, Comoros, Congo DR, Congo Republic, Côte d'Ivoire, Egypt, 
Ethiopia, Gabon, Gambia, Ghana, Guinea-Bissau, Kenya, Lesotho, Liberia, Madagascar, Malawi, Mali, Mauritius, Morocco, Mozambique, Namibia, Niger, Nigeria, Rwanda, Senegal, Seychelles, Sierra Leone, South Africa, Sudan, Tanzania, Togo, Tunisia, Uganda and Zambia. These African countries were chosen for this study on the basis of data availability. The study centred on the post-GFC period and therefore, the time scope of the study is 2010-2018.

Table 2: Variables and data sources

\begin{tabular}{|c|c|c|}
\hline Variable & Definition & Data source \\
\hline $\boldsymbol{Y}$ & Real GDP per capita in constant 2010 US\$ & $\begin{array}{l}\text { World Bank's World } \\
\text { Development Indicators (WDI) }\end{array}$ \\
\hline$A I D$ & $\begin{array}{l}\text { Foreign aid, defined as net official development } \\
\text { assistance and official aid received (constant } 2015 \text { US\$) } \\
\text { measured as percentage of GDP }\end{array}$ & $\begin{array}{l}\text { World Bank's World } \\
\text { Development Indicators (WDI) }\end{array}$ \\
\hline $\mathrm{COC}$ & $\begin{array}{l}\text { Control of corruption, which is a measure of institutional } \\
\text { quality expressed in percentile rank from } 1 \text { (lowest level) } \\
\text { to } 100 \text { (highest level) }\end{array}$ & $\begin{array}{l}\text { World Bank's World } \\
\text { Governance Indicators (WGI) }\end{array}$ \\
\hline GE & $\begin{array}{l}\text { Government effectiveness, which is a measure } \\
\text { of institutional quality expressed in percentile rank from } 1 \\
\text { (lowest level) to } 100 \text { (highest level) }\end{array}$ & $\begin{array}{l}\text { World Bank's World } \\
\text { Governance Indicators (WGI) }\end{array}$ \\
\hline TOP & $\begin{array}{l}\text { Trade openness, which is the sum of exports and imports } \\
\text { of goods and services expressed as a percentage of GDP }\end{array}$ & $\begin{array}{l}\text { World Bank's World } \\
\text { Development Indicators (WDI) }\end{array}$ \\
\hline$K$ & $\begin{array}{l}\text { Capital, measured as gross capital formation in percent } \\
\text { of GDP }\end{array}$ & $\begin{array}{l}\text { World Bank's World } \\
\text { Development Indicators (WDI) }\end{array}$ \\
\hline $\boldsymbol{L}$ & $\begin{array}{l}\text { Labour, measured with the human development index } \\
\text { expressed in percentage terms }\end{array}$ & $\begin{array}{l}\text { United Nations Development } \\
\text { Programme (UNDP) }\end{array}$ \\
\hline
\end{tabular}

Note: All the variables were logged prior to estimation. In the case of the Human Development Index, which ranges between 0 and 1 , we expressed it in percentage terms by multiplying it by 100 before logging it.

Source: Authors' calculations

The descriptive statistics and the correlation matrix of the raw data are shown in Table 3. This table shows the number of observations, mean, standard deviation, minimum and maximum values of the data.

The summary statistics of the variables as shown in Table 3 indicate that the minimum, average and maximum real GDP per capita in Africa over the period of study are US\$ 210.80 recorded by Burundi in 2018, US\$ 2 478.39, and US\$ 14,417.06 recorded by Seychelles in 2018, respectively. The standard deviation of 2885.60 shows that real GDP per capita varied remarkably across the countries. The average trade openness 
in the region is $73 \%$, the minimum level of trade openness is $19 \%$, while the maximum value is $216 \%$. It is also evident that the average foreign aid as a share of GDP in Africa within the period of this study is $6.44 \%$. The study found that the lowest foreign aid share of $0.01 \%$ was recorded by Egypt in 2017, and the highest share of $66.54 \%$ was recorded by Liberia in 2010. The summary statistics for institutional quality variables exhibit a clear pattern. Both variables have the same minimum and maximum values. The data show that Botswana, Cabo Verde, Mauritius, Rwanda and Seychelles are associated with high levels of institutional quality within the study period, while Ghana, South Africa and Tunisia have an average level of institutional quality. The rest of the countries are below $50 \%$, signifying poor institutional quality. The correlation matrix of the regressors shows that there is no problem of collinearity with the exception of institutional quality variables. The two institutional quality variables (i.e., control of corruption and government effectiveness) exhibited a clear sign of high collinearity with a correlation of 0.86 between them. Therefore, the control of corruption and government effectiveness variables were included in different models to avoid the problem of collinearity.

Table 3: Summary statistics of variables and correlation matrix

\begin{tabular}{l|r|r|r|r|r|r|r}
\hline Variables & \multicolumn{1}{|c|}{$\boldsymbol{Y}$} & $\boldsymbol{A I I}$ & COC & GE & TOP & $\boldsymbol{K}$ & $\boldsymbol{L}$ \\
\hline Mean & 2478.395 & 6.441 & 34.007 & 30.458 & 72.824 & 24.809 & 0.540 \\
\hline Std. Dev. & 2885.603 & 7.111 & 22.101 & 20.296 & 34.714 & 9.055 & 0.112 \\
\hline Min. & 210.804 & 0.012 & 0.947 & 0.948 & 19.101 & 4.704 & 0.319 \\
\hline Max. & 14417.060 & 66.549 & 81.905 & 81.731 & 216.483 & 53.988 & 0.801 \\
\hline Skewness & 1.939 & 2.950 & 0.483 & 0.575 & 1.280 & 0.616 & 0.610 \\
\hline Kurtosis & 6.296 & 18.887 & 2.181 & 2.357 & 4.932 & 3.182 & 2.460 \\
\hline
\end{tabular}

Correlation Matrix

\begin{tabular}{l|c|c|c|c|c|c|c}
\hline $\boldsymbol{Y}$ & 1.000 & & & & & & \\
\hline $\boldsymbol{A I D}$ & -0.457 & 1.000 & & & & & \\
\hline $\boldsymbol{C O C}$ & 0.506 & -0.142 & 1.000 & & & & \\
\hline $\boldsymbol{G E}$ & 0.617 & -0.303 & 0.863 & 1.000 & & & \\
\hline $\boldsymbol{T O P}$ & 0.508 & -0.003 & 0.392 & 0.296 & 1.000 & & \\
\hline $\boldsymbol{K}$ & 0.231 & -0.188 & 0.310 & 0.282 & 0.346 & 1.000 & \\
\hline $\boldsymbol{L}$ & 0.837 & -0.535 & 0.527 & 0.647 & 0.392 & 0.236 & 1.000 \\
\hline
\end{tabular}

Note: The variable definitions and units of measurement are as shown in Table 2.

Source: Authors' calculations 
The study adopted a dynamic panel data modelling approach. The use of a dynamic panel data estimator is more suitable in cases where some unobservable factors affect both the dependent variable and the explanatory variables in a way that some explanatory variables are intensely correlated to previous values of the dependent variable. This is usually the case in growth equations. However, dynamic short panel specification is further justified for this study given the small panel available for the study. The study used robustness tests for the system GMM as proposed by Arellano and Bover (1995) and Blundell and Bond (1998) to validate the results.

The preference for the dynamic system GMM panel model is based mainly on the significant characteristics identified as follows. Firstly, the dynamic nature of economic growth requires a system GMM that corrects for unobserved country heterogeneity, which is typical of African economies. Secondly, it addresses the problem of estimation omission of static panels (Baum and Christopher, 2006), which are usually mis-specified because the impact of the lagged dependent variable is not taken into consideration (Bond, 2002). Thirdly, system GMM helps to address the problem of endogeneity since sometimes there could be correlation between an independent variable and the error term in the model, and this is easily addressed in dynamic panels by including the lag of the dependent variable in the model (Roodman, 2009). Fourthly, it has been argued by Blundell and Bond (1998) that the system GMM estimator is more efficient than the instrumental variable estimator even in the presence of heteroscedasticity. Likewise, in the absence of heteroscedasticity, the instrumental variable is not preferred asymptotically than system GMM estimator. Finally, the system GMM robust estimator makes the standard error consistent even in the presence of persistent series and heteroscedasticity (Blundell and Bond, 1998; Bond et al., 2001).

\section{Results}

To ensure that the decision of this study to adopt the system GMM estimator rather than the difference GMM estimator is not misplaced, this empirical analysis began by performing the Bond (2002) test in order to determine the appropriate estimator between the difference and system GMM estimators. The results overwhelmingly favoured the system GMM estimator (see Appendix 2). The empirical results of this study are presented in Table 4 based on the system GMM estimations. In this table, Panel A reports the baseline estimation, which excluded the interaction term $(A I D \times C O C)$, while Panel $\mathrm{B}$ reports the same model with the inclusion of this interaction term. Panels $\mathrm{C}$ and $\mathrm{D}$ provide some robustness checks for the study. In Panel C, government effectiveness is used as a measure of institutional quality in place of control of corruption without an interaction term, while Panel D includes the interaction term $(A I D \times G E)$. 
The results indicate that foreign aid has a negative and statistically significant effect on economic growth throughout. This suggests that foreign aid by itself alone may not be sufficient in driving economic growth in Africa. It could also suggest that even though emergency aid may be necessary for human welfare, foreign aid has not been effective in engendering growth in Africa. This result is consistent with Moyo, (2010), Bräutigam and Knack, (2004) and Rajan and Subramanian (2005). These studies found that in developing countries, foreign aid does have a negative relationship with economic growth. The result is also consistent with empirical evidence that shows an inverse relation between unearned income intensity and growth (Arellano et al., 2009), implying that aid dependence impedes economic growth.

Table 4: Two-step system GMM dynamic panel estimation results

\begin{tabular}{|c|c|c|c|c|}
\hline & (Panel A) & (Panel B) & (Panel C) & (Panel D) \\
\hline Variables & SGMM2 & SGMM2 & SGMM2 & SGMM2 \\
\hline L.y & $\begin{array}{l}0.956^{* * *} \\
(0.006)\end{array}$ & $\begin{array}{l}0.977^{* * * *} \\
(0.009)\end{array}$ & $\begin{array}{l}0.947^{* * *} \\
(0.006)\end{array}$ & $\begin{array}{l}0.884^{* * * *} \\
(0.010)\end{array}$ \\
\hline$A I D$ & $\begin{array}{l}-0.005^{* * *} \\
(0.000)\end{array}$ & $\begin{array}{l}-0.008^{* * *} \\
(0.002)\end{array}$ & $\begin{array}{l}-0.011^{* * *} \\
(0.002)\end{array}$ & $\begin{array}{c}-0.013^{*} \\
(0.008)\end{array}$ \\
\hline $\operatorname{coc}$ & $\begin{array}{l}0.005^{* * * *} \\
(0.001)\end{array}$ & $\begin{array}{l}0.006^{*} \\
(0.002)\end{array}$ & & \\
\hline$A I D \times C O C$ & & $\begin{array}{l}0.011^{* * * *} \\
(0.001)\end{array}$ & & \\
\hline GE & & & $\begin{array}{l}0.014^{* * *} \\
(0.002)\end{array}$ & $\begin{array}{c}0.003 \\
(0.004)\end{array}$ \\
\hline$A I D \times G E$ & & & & $\begin{array}{l}0.018^{* * *} \\
(0.004)\end{array}$ \\
\hline TOP & $\begin{array}{l}0.003^{* * *} \\
(0.002)\end{array}$ & $\begin{array}{l}0.017^{* * *} \\
(0.004)\end{array}$ & $\begin{array}{l}0.017^{* * *} \\
(0.003)\end{array}$ & $\begin{array}{l}0.037^{* * *} \\
(0.004)\end{array}$ \\
\hline$K$ & $\begin{array}{l}0.061^{* * *} \\
(0.005)\end{array}$ & $\begin{array}{l}0.007^{*} \\
(0.004)\end{array}$ & $\begin{array}{l}0.023^{* * *} \\
(0.003)\end{array}$ & $\begin{array}{l}0.016^{* * *} \\
(0.006)\end{array}$ \\
\hline$L$ & $\begin{array}{l}0.122^{* * *} \\
(0.030)\end{array}$ & $\begin{array}{c}0.046 \\
(0.034)\end{array}$ & $\begin{array}{l}0.114^{* * * *} \\
(0.024)\end{array}$ & $\begin{array}{l}0.321^{* * *} \\
(0.030)\end{array}$ \\
\hline Constant & $\begin{array}{c}-0.362^{* * *} \\
(0.081)\end{array}$ & $\begin{array}{l}-0.356^{* * *} \\
(0.083)\end{array}$ & $\begin{array}{c}-0.224^{* * *} \\
(0.056)\end{array}$ & $\begin{array}{l}0.641^{* * *} \\
(0.087)\end{array}$ \\
\hline Observations & 336 & 336 & 336 & 336 \\
\hline Number of crossid & 42 & 42 & 42 & 42 \\
\hline Hansen Prob & 0.517 & 0.612 & 0.257 & 0.395 \\
\hline Diff-in-Hansen Prob & 0.852 & 0.519 & 0.453 & 0.100 \\
\hline AR(1)_P-value & 0.049 & 0.083 & 0.036 & 0.035 \\
\hline AR(2)_P-value & 0.241 & 0.189 & 0.226 & 0.220 \\
\hline
\end{tabular}

Notes: Standard errors are reported in parentheses. ${ }^{* * *} p<0.01,{ }^{* *} p<0.05,{ }^{*} p<0.1$. SGMM2 denotes two-step system GMM. All the variables are as defined in Equation (3).

Source: Authors' computations 
Interestingly, the results indicate that the two measures of institutional quality recorded positive and statistically significant coefficients in all cases, except Panel D. This finding shows that institutional quality plays an important role as a driver of growth in Africa. This finding, which is consistent with the findings of Flachaire et al. (2014) and Kodongo and Ojah (2016), suggests that Africa's level of institutional quality and the channels in which the institutional quality transmits to economic growth require greater attention to enhance economic growth on the continent. This finding is also consistent with Rodrik (2003) and Lee and Kim (2009), indicating that the fight to improve institutional quality matters for all economies in stimulating economic growth. Hall and Jones (1999) contend that sustainable economic growth in any economy is driven by institutions that provide conducive environments for economic agents to engage in productive activities.

This study emphasizes the interactive effect between foreign aid and institutional quality. The coefficient of the interactive term is positive and significant in all the cases. This finding indicates that the interaction term has a positive relationship with economic growth. Since the coefficients of foreign aid and the interaction term have different signs, it shows that foreign aid is a curse while institutional quality is positively moderating that curse towards becoming a blessing. This implies that as control of corruption or government effectiveness improves in Africa, aid development plans can be carried out and implemented gainfully, so they would then be capable of engendering growth. Specifically, Panels B and D of Table 4 show the results of the interaction between foreign aid and institutional quality in order to determine whether the effect of foreign aid on economic growth differs with the various levels of institutional quality. This study computed the marginal effects of foreign aid at different levels of institutional quality. Hence, the marginal effect of foreign aid on economic growth using Equation (4) is calculated thus:

$$
\frac{\partial y_{i t}}{\partial a i d_{i t}}=-0.42144+0.551815 \operatorname{coc}_{i t}
$$

Therefore, the marginal effects of foreign aid on economic growth at different levels of institutional quality are $-0.4162,-0.2338$ and 0.0305 for minimum, average and maximum levels of institutional quality, respectively (details of these computations are provided in Appendix 3). Hence, a percentage increase in foreign aid would decrease economic growth by $41.62 \%$ and $23.38 \%$ at the minimum and average levels of institutional quality, respectively. Conversely, a percentage increase in foreign aid would increase economic growth by $3.05 \%$ at the maximum level of institutional quality. This implies that, in Africa, the marginal effect of foreign aid on economic growth is positive at a high level of institutional quality and negative at a low level of institutional quality. This is consistent with the theoretical and empirical literature that high-quality institutions will not only spur 
growth, but will also improve the effectiveness of foreign aid (Demsetz, 1967; La Porta et al., 1999; Acemoğlu and Robinson, 2010b; Ogbuabor et al., 2019; Maruta et al., 2020). This finding also suggests that as the level of institutional quality improves, the adverse effect of foreign aid on growth diminishes. The institutional quality threshold beyond which foreign aid becomes a blessing to Africa is computed at $76 \%$ (see Appendix 3). Below this threshold, foreign aid is a curse to Africa. Since the average level of institutional quality in Africa is below this threshold, it implies that the institutional quality in Africa is too weak to overturn the inherent curse of foreign aid. The countries in Africa that are showing considerably high levels of institutional quality capable of engendering growth are Botswana, Cabo Verde and Seychelles. Indeed, a major contribution of this study to the literature is the computation of the threshold level of institutional quality beyond which the positive effect of foreign aid on economic growth begins to manifest in Africa. The implication of this finding is that governments in Africa should focus attention on institutional quality in order to improve growth. This finding is expected to uplift the institutional quality consciousness among African economies to a level that can engender investors' confidence and healthy competition among economic agents.

With regard to the other control variables in this study, there is clear evidence of a positive growth effect of trade openness, physical and human capital, which is consistent with economic theory. The trade-led growth hypothesis emphasizes that trade openness improves growth through spillover effects. The endogenous growth model explains that exposure to the world market through global trade provides an open economy with more possibility to grow faster than a closed economy. It equally buttresses the significant effect of human capital on growth, which makes investment in human capital germane for economic sustainability. The results also indicate that the initial level of per capita GDP is an important driver of growth in Africa. This finding is consistent with studies such as Levine and Renelt (1992), which also established that the initial level of real GDP per capita is an important determinant of GDP per capita growth. However, contrary to theoretical expectation, we find in Panel B that human and physical capital play an insignificant and weak role in spurring growth in African economies, respectively. Nonetheless, this unexpected result is consistent with some earlier studies that found capital to be either weak or insignificantly related to growth in Africa (Nwabu, 2005; Omotor, 2007; Ogbonna et al., 2020). This insignificant relationship could be attributed to inefficiency in the use of capital since many African economies have large volumes of unearned income, which covertly lowers the incentive to optimize the use of resources (Bräutigam and Knack, 2004; Ogbonna et al., 2020).

This study subjected the models in Table 4 to two important diagnostic tests, which are the Arellano-Bond second-order (AR2) test for serial correlation and the Hansen test 
of overidentifying restrictions. The results of these tests indicate that the models are suitable for inference and policy.

\section{Concluding Remarks}

This study examined the dynamic relationship between foreign aid and economic growth in Africa while controlling for the moderating effect of institutional quality. A panel of forty-two African countries was used over the post-crisis period 2010-2018. The study also used the two-step system GMM modelling framework. The choice of the system GMM estimation method became necessary not only due to the short panel available for the study and the dynamic nature of the model, but also to ensure that the results can be compared to some recent evidence in the literature. The study established that foreign aid has so far not promoted economic growth in Africa mainly due to the so-called "aid syndrome". This finding shows that the argument that unearned income dependence negatively affects growth remains tenable in Africa. This study demonstrated that such negative effects can be moderated by strengthening the quality of institutions in Africa. An important policy implication of this finding is that policymakers in Africa should understand that institutional quality is an important ingredient for engendering growth on the continent. This study shows that the predominantly weak institutional frameworks in Africa could explain why Africa is still struggling to leverage the continent's huge foreign aid to drive growth and reduce the excruciating effects of poverty plaguing more than half of its population. The aid-curse syndrome identified as the coexistence of vast aid in the region and extreme poverty could be part of the reasons why the resources in Africa do not trickle down to address her economic growth sustainability needs. Therefore, structural transformation is needed to correct the existing structural distortions in Africa, such that nations in the region should improve the quality of their institutions in order to utilize foreign aid more judiciously to enhance growth and development.

Furthermore, the results also indicate that trade openness, human and physical capital accumulation, and initial real GDP per capita are robust drivers of growth in Africa. Therefore, policy reforms in Africa should be aimed at enhancing the socio-economic environment on the continent to a level that can engender high levels of human capital development, enhanced physical capital accumulation, and greater trade openness. This can be realized through the elimination of barriers to trade and improvements in basic infrastructure to drive investment and productivity. Policies and strategies along these lines will ensure that Africa's common goal of shared prosperity and improved living standards for all its citizens are achieved on a sustainable basis. 


\section{Appendices}

\section{Appendix 1: Partial derivative}

Here, we show that given Equation (3), the partial derivative of $y_{i, t}$ with respect to aid ${ }_{i, t}$ is as shown in Equation (4).

Proof: Since Equation (3) is dynamic such that $y_{i t}$ depends on $y_{i, t-1}$, it follows that:

$$
\therefore \frac{\partial y_{i t}}{\partial a i d_{i t}}=\phi_{1}(\partial) y_{i t-1}+\beta_{1}+\beta_{3} \operatorname{coc}_{i t}
$$

But $y_{i t-1}=\alpha_{i}+\varphi_{i 1} y_{i t-2}+\beta_{i 1} \operatorname{aid}_{i t-1}+\beta_{i 2} \operatorname{coc}_{i t-1}+\beta_{i 3}\left(\operatorname{aid}_{i t-1} \times \operatorname{coc}_{i t-1}\right)+\cdots$

where $\Lambda$ denotes the remaining components of Equation (3)

$$
\therefore \frac{\partial y_{i t-1}}{\partial a i d_{i t-1}}=\phi_{1}(\partial) y_{i t-2}+\beta_{1}+\beta_{3} \operatorname{coc}_{i t-1}
$$

But $y_{i t-2}=\alpha_{\mathrm{i}}+\phi_{i 1} y_{i t-3}+\beta_{i 1} \operatorname{aid}_{i t-2}+\beta_{i 2} \operatorname{coc}_{i t-2}+\beta_{i 3}\left(\operatorname{aid}_{i t-2} \times \operatorname{coc}_{i t-2}\right)+\ldots$

$$
\therefore \frac{\partial y_{i t-2}}{\partial a i d_{i t-2}}=\phi_{1}(\partial) y_{i t-3}+\beta_{1}+\beta_{3} \operatorname{coc}_{i t-2}
$$

This process goes on indefinitely; such that by substituting Equations (A2), (A3), and so on, into Equation (A1), we find that the partial derivative of $y_{i, t}$ with respect to $a d_{i, t}$ is then given by:

$$
\begin{aligned}
& \frac{\partial y_{i t}}{\partial a i d_{i t}}=\left[1+\phi_{1}+\phi_{1}^{2}+\ldots\right]\left(\beta_{1}+\beta_{3} \operatorname{coc}_{i t}\right) \\
& \therefore \frac{\partial y_{i t}}{\partial a i d_{i t}}=\left[1 /\left(1-\phi_{i t}\right)\right]\left(\beta_{1}+\beta_{3} \operatorname{coc}_{i t}\right)
\end{aligned}
$$

Appendix 2: Bond test results

\begin{tabular}{l|c|c}
\hline Bond Test & Model Without Interaction Term & Model With Interaction Term \\
\hline Pooled OLS & $0.99141^{* * *}$ & $0.99274^{* * *}$ \\
\hline Fixed Effect & $0.72751^{* * *}$ & $0.72782^{* * *}$ \\
\hline 1st_Diff (DGMM1) & $0.51036^{* * *}$ & $0.30696^{* * *}$ \\
\hline 2nd_Diff (DGMM2) & $0.54352^{* * *}$ & $0.30807^{* * *}$ \\
\hline Decision & System GMM & System GMM \\
\hline
\end{tabular}




\section{Appendix 3: Computing the threshold level of institutional quality}

To compute the threshold level of institutional quality variables, the study equates the expression in Equation 5 (i.e., the marginal difference) to 0 (zero), thus:

$$
\begin{array}{lr}
\frac{\partial y_{i t}}{\partial a i d_{i t}}=\left[\frac{1}{1-0.98}\right]\left(-0.0084288+0.0110363 \operatorname{coc}_{i t}\right) & \frac{\partial y_{i t}}{\partial a i d_{i t}}=\left[\frac{1}{1-0.88}\right]\left(-0.013124+0.01829 g e_{i t}\right) \\
=-0.42144+0.551815 \operatorname{coc}_{i t} & =-0.109329+0.1523557 \mathrm{ge}_{i t} \\
\therefore-0.42144+0.551815 \operatorname{coc}_{i t}=0 & \therefore-0.109329+0.1523557 g e_{i t}=0 \\
0.551815 \operatorname{coc}_{i t}=0.42144 & 0.1523557 g e_{i t}=0.109329 \\
\operatorname{coc}_{i t}=0.42144 / 0.551815 & g e_{i t}=0.109329 / 0.1523557 \\
\operatorname{coc}_{i t}=0.7637=76 \% & g e_{i t}=0.7176=72 \%
\end{array}
$$

From the descriptive statistics in Table 3, the minimum, average and maximum control of corruption (which is the main proxy for institutional quality in this study) is found to be at $0.95 \%, 34.01 \%$ and $81.90 \%$ respectively. Therefore, we compute the marginal effects of foreign aid at minimum, average and maximum levels of institutional quality as follows:

$$
\frac{\partial y_{i t}}{\partial a i d_{i t}}=-0.42144+0.551815 \operatorname{coc}_{i t}
$$

\begin{tabular}{c|l|l}
\hline \multicolumn{1}{c|}{ Minimum } & \multicolumn{1}{|c}{ Average } & \multicolumn{1}{c}{ Maximum } \\
\hline$\frac{\partial y_{i t}}{\partial a i d_{i t}}=-0.42144+$ & $\frac{\partial y_{i t}}{\partial a i d_{i t}}=-0.42144+$ & $\frac{\partial y_{i t}}{\partial a i d_{i t}}=-0.42144+$ \\
$+0.551815(0.0095)$ & $+0.551815(0.3401)$ & $+0.551815(0.8190)$ \\
$=-0.4162$ & $=-0.2338$ & $=-0.0305$ \\
\hline
\end{tabular}

\section{References}

Acemoğlu, D., Robinson, J. A. (2010a). Why is Africa Poor? Economic History of Developing Regions, 25(1), 21-50, https://doi.org/10.1080/20780389.2010.505010

Acemoğlu, D., Robinson, J. A. (2010b). The Role of Institutions in Growth and Development, in Brady, D., Spence, M., eds., Leadership and Growth. Washington, DC: The World Bank, pp. 135-164, https://doi.org/10.1596/978-0-8213-8100-7 
Acemoğlu, D., Robinson, J. A. (2012). Why Nations Fail: The Origins of Power, Prosperity, and Poverty. New York City: Crown Publishing Group. ISBN 9781847654618

Arellano, C., Bulíŕ, A., Lane, T., et al. (2009). The Dynamic Implications of Foreign Aid and its Variability. Journal of Development Economics, 88(1), 87-102, https://doi.org/10.1016/j. jdeveco.2008.01.005

Arellano, M., Bond, S. (1991). Some tests of specification for panel data: Monte Carlo evidence and an application to employment equations. The Review of Economic Studies, 58(2), 277-297, https://doi.org/10.2307/2297968

Arellano, M., Bover, O. (1995). Another Look at the Instrumental Variable Estimation of Error-components Models. Journal of Econometrics, 68(1), 29-51, https://doi.org/10.1016/0304-4076(94)01642-D

Baum, C. F. (2006). An Introduction to Modern Econometrics using Stata. Texas: Stata Press. ISBN 978-1-59718-013-9.

Blundell, R., Bond, S. (1998). Initial Conditions and Moment Restrictions in Dynamic Panel Data Models. Journal of Econometrics, 87(1), 115-143, https://doi.org/10.1016/ S0304-4076(98)00009-8

Bond, S. R. (2002). Dynamic Panel Data Models: A Guide to Micro Data Methods and Practice. Portuguese Economic Journal, 1(2), 141-162, https://doi.org/10.1007/s10258-002-0009-9

Bond, S. R., Hoeffler, A., Temple, J. (2001). GMM Estimation of Empirical Growth Models. Centre for Economic Policy Research. London Discussion Paper No. 2048.

Brambor, T., Clark, W. R., Golder, M. (2006). Understanding Interaction Models: Improving Empirical Analyses. Political Analysis, 14(1), 63-82, https://doi.org/10.1093/pan/mpi014

Bräutigam, D. A., Knack, S. (2004). Foreign Aid, Institutions, and Governance in sub-Saharan Africa. Economic Development and Cultural Change, 52(2), 255-285, https://doi.org/10.1086/380592

Burnside, C., Dollar, D. (2000). Aid, Policies, and Growth. American Economic Review, 90(4), 847-868, https://doi.org/10.1257/aer.90.4.847

Christensen, Z., Homer, D., Nielson, D. L. (2011). Dodging Adverse Selection: How Donor Type and Governance Condition Aid's Effects on School Enrollment. World Development, 39(11), 2044-2053, https://doi.org/10.1016/j.worlddev.2011.07.018

Clemens, M. A., Radelet, S., Bhavnani, R. R., et al. (2012). Counting Chickens When They Hatch: Timing and the Effects of Aid on Growth. The Economic Journal, 122(561), 590-617, https://doi.org/10.1111/j.1468-0297.2011.02482.x

Demsetz, H. (1967). Toward A Theory of Property Rights. American Economic Review, 62, 347-359, https://doi.org/10.1057/9780230523210_9

Devarajan, S., Miller, M. J., Swanson, E. V. (2002). Goals for Development: History, Prospects, and Costs. Washington DC: The World Bank, https://doi.org/10.1596/1813-9450-2819

Dias, J., Tebaldi, E. (2012). Institutions, Human Capital, and Growth: The Institutional Mechanism. Structural Change and Economic Dynamics, 23(3), 300-312, https://doi.org/10.1016/j.strueco.2012.04.003 
Djankov, S., Montalvo, J. G., Reynal-Querol, M. (2008). The Curse of Aid. Journal of Economic Growth, 13(3), 169-194, https://doi.org/10.1007/s10887-008-9032-8

Edwards, S. (2015). Economic Development and the Effectiveness of Foreign Aid: A Historical Perspective. Kyklos, 68(3), 277-316, https://doi.org/10.1111/kykl.12084

Ehigiamusoe, K. U., Lean, H. H. (2019). Influence of Real Exchange Rate on the Financegrowth Nexus in the West African Region. Economies, 7(1), 23, https://doi.org/ 10.3390/economies7010023

Ekanayake, E. M., Chatrna, D. (2010). The Effect of Foreign Aid on Economic Growth in Developing Countries. Journal of International Business and Cultural Studies, 3(1), 1-13.

Flachaire, E., García-Peñalosa, C., Konte, M. (2014). Political versus Economic Institutions in the Growth Process. Journal of Comparative Economics, 42(1), 212-229, https://doi.org/10.1016/j.jce.2013.05.001

Hall, R. E., Jones, C. I. (1999). Why do Some Countries Produce so much more Output per Worker than Others? The Quarterly Journal of Economics, 114(1), 83-116, https://doi.org/10.1162/003355399555954

Hansen, H., Tarp, F. (2000). Aid Effectiveness Disputed. Journal of International Development, 12(3), 375-398, https://doi.org/10.1002/(SICI)1099-1328(200004) 12:3<375::AIDJID657>3.0.CO;2-M

Juselius, K., Møller, N. F., Tarp, F. (2014). The Long-run Impact of Foreign Aid in 36 African Countries: Insights from Multivariate Time Series Analysis. Oxford Bulletin of Economics and Statistics, 76(2), 153-184, https://doi.org/10.1111/obes.12012

Kalirajan, K., Otsuka, K. (2014). Fiscal Decentralization and Development Outcomes in India, in Otsuka, K., Shiraishi, T., eds., State Building and Development. London: Routledge, pp. 139-156. ISBN 9781138918122

Kalu, K. (2018). Targeting the Fundamentals: Towards a New Form of Development Assistance to Africa, in Kalu, K., ed., Foreign Aid and the Future of Africa. London: Palgrave Macmillan, pp. 109-144. ISBN 9783319789873, https://doi.org/10.1007/978-3-319-78987-3_6

Kang, J. S., Prati, A., Rebucci, A. (2012). Aid, Exports, and Growth: A Time-series Perspective on the Dutch Disease Hypothesis. Review of Economics and Institutions, 3(2), 26-40, http://doi.org/10.5202/rei.v3i2.76

Kodongo, O., Ojah, K. (2016). Does Infrastructure Really Explain Economic Growth in Sub-Saharan Africa? Review of Development Finance, 6(2), 105-125, https://doi.org/10.1016/j.rdf.2016.12.001

La Porta, R., Lopez-de-Silanes, F., Shleifer, A., et al. (1999). The Quality of Government. The Journal of Law, Economics, and Organization, 15(1), 222-279, https://doi.org/10.1093/ jleo/15.1.222

Lee, K., Kim, B. Y. (2009). Both Institutions and Policies Matter but Differently for Different Income Groups of Countries: Determinants of Long-run Economic Growth Revisited. World Development, 37(3), 533-549, https://doi.org/10.1016/j.worlddev.2008.07.004 
Levine, R., Renelt, D. (1992). A Sensitivity Analysis of Cross-country Growth Regressions. The American Economic Review, 82(4), 942-963. Available at: https://www.jstor.org/ stable/2117352

Lof, M., Mekasha, T. J., Tarp, F. (2015). Aid and Income: Another Time-series Perspective. World Development, 69(5), 19-30, https://doi.org/10.1016/j.worlddev.2013.12.015

Maruta, A. A., Banerjee, R., Cavoli, T. (2020). Foreign Aid, Institutional Quality and Economic Growth: Evidence from the Developing World. Economic Modelling, 89(6), 444-463, https://doi.org/10.1016/j.econmod.2019.11.008

Morrissey, O. (2001). Does Aid Increase Growth? Progress in Development Studies, 1(1), 37-50, https://doi.org/10.1177/146499340100100104

Moyo, D. (2010). Dead Aid: Why Aid Makes Things Worse and How There is Another Way for Africa. United Kingdom: Penguin Books. ISBN 9780141031187.

North, D. C. (1990). Institutions, Institutional Change, and Economic Performance. New York: Cambridge University Press. ISBN 9780511808678, https://doi.org/10.1017/ CBO9780511808678

Nwabu, G. (2005). Human Capital Investment, Growth and Poverty Reduction in Sub-Saharan Africa. AERC Senior Policy Seminar VII, African Economic Research Consortium, Nairobi, Kenya.

Ogbonna, O. E., Mobosi, I. A., Ugwuoke, O. W. (2020). Economic Growth in an Oil-dominant Economy of Nigeria: The Role of Financial System Development. Cogent Economics \& Finance, 8(1), 1810390, https://doi.org/10.1080/23322039.2020.1810390

Ogbuabor, J. E., Anthony-Orji, O. I., Ogbonna, O. E., et al. (2019). Regional Integration and Growth: New Empirical Evidence from WAEMU. Progress in Development Studies, 19(2), 123-143, https://doi.org/10.1177/1464993418822883

Omotor, D. (2007). Financial System Development and Economic Growth: Empirical Evidence from Nigeria. The Nigerian Journal of Economic and Social Studies, 49(2), 209-233.

Pagano, M. (1993). Financial Markets and Growth: An Overview. European Economic Review, 37(2-3), 613-622, https://doi.org/10.1016/0014-2921(93)90051-B

Rajan, R. G., Subramanian, A. (2005). What Undermines Aid's Impact on Growth? National Bureau of Economic Research. Cambridge, MA Working Paper No. w11657, https://doi.org/10.3386/w11657

Rodrik, D. (ed.) (2003). In Search of Prosperity: Analytic Narratives on Economic Growth. Princeton, Oxford: Princeton University Press. Available at: https://www.jstor.org/ stable/j.ctt1r2fkg

Romer, D. (2012). Infinite-Horizon and Overlapping-Generations Models, in Advanced Macroeconomics. (4 ${ }^{\text {th }}$ Ed.). New York: McGraw Hill, pp. 49-100. ISBN 9780073511375.

Roodman, D. (2009). A Note on the Theme of Too Many Instruments. Oxford Bulletin of Economics and Statistics, 71(1), 135-158, https://doi.org/10.1111/j.1468-0084.2008.00542.x

Sachs, J. D. (2005). The End of Poverty: Economic Possibilities for Our Time. New York: Penguin Group. ISBN 9780143036586. 
Schmieg, E. (2015). Trade Policy Options for Sub-Saharan Africa, TTIP, EPAs, WTO and African Integration. Stiftung Wissenschaft und Politik (SWP), German Institute for International and Security Affairs. SWP Comments 23, pp. 1-8. ISSN 1861-1761.

Solow, R. M. (1956). A Contribution to the Theory of Economic Growth. The Quarterly Journal of Economics, 70(1), 65-94, https://doi.org/10.2307/1884513

Swan, T. W. (1956). Economic Growth and Capital Accumulation. Economic Record, 32(2), 334-361, https://doi.org/10.1111/j.1475-4932.1956.tb00434.x

World Bank (2020). PovcalNet: The On-line Tool for Poverty Measurement. Washington DC: Development Research Group, The World Bank. [Retrieved 2020-08-25] Available at: http://iresearch.worldbank.org/PovcalNet/Archive.aspx?5,0,20200317 